\title{
The Illusion of Free Will and the Prominence of Coincidence in the Films of Buster Keaton and Charlie Chaplin
}

\author{
Surya Prakash Verma and Binod Mishra
}

\begin{abstract}
Two great masters of silent cinema-Buster Keaton and Charlie Chaplin, although from two different milieus, seem to be aware of the fact that it is the unconscious actions or the coincidences that contribute immensely to whatever we become in our lives. Sam Harris, an American philosopher and neuroscientist, in his book Free Will (2012), announces that freedom of choice-making is nothing more than an illusion. It is not only the choices that we make in our lives which are highly constrained, but also the consequences of these choices depend on many other factors-visible or invisible. The present article looks into the coincidences portrayed in the films of Chaplin and Keaton. The article establishes a proposition contrasting with the idea of freedom of choice in Sartre's Existentialism and offers a parallel between the idea propounded by Sam Harris in his book Free Will and the philosophy of these two filmmakers. Buster Keaton's The Navigator (1924) and The General (1926) while Charles Chaplin's The City Lights (1931) and Modern Times (1936) are the films that have been examined in the article as primary texts for drawing the conclusion.
\end{abstract}

Keywords: Illusion of Free Will, Coincidence, Charles Chaplin, Buster Keaton, Silent Comedy.

\section{Introduction}

What if the voice of Charles Spencer Chaplin's mother had not "cracked during the Jack Jones song" (Stassi, 2012, p. 39), on the stage when he was five? Or, what if Mack Sennett had not suggested, as Chaplin has mentioned in his autobiography-'put on a comedy makeup. Anything will do [?]' (1964, p. 145) The former incident led Chaplin to act for the first time before the audience while the latter gave birth to his monumental The Little Tramp screen persona. Is it not that more such coincidences shape our life? A famous university teacher once claimed: My birth is mere coincidence. The claim, it can be argued, was not illogical. Most of the important things in our life often occur without any of our conscious efforts. The existential approach of life might have provided us with the illusion of free will, but it does not necessarily play a prominent role in shaping our existence. Sam Harris points out the problems of freedom of choice-making in his book Free Will:

Free will is actually more than an illusion (or less), in that it cannot be made conceptually coherent. Either our wills are determined by prior causes and we are not responsible for them, either they are the product of chance and we are not responsible for them. (Harris, 2012, p. 18) 
For any event to look like a coincidence, it demands the absence of any likely cause, or the presence of the most unlikely cause. Suppose, any point A is likely to be reached only by taking route $\mathrm{a}, \mathrm{b}$, or $\mathrm{c}$, but someone who follows the unlikely route $\mathrm{d}$ and also reaches the point A. Now, we consider the event as a coincidence. We find ourselves in a favourable position when they occur in our lives. When a coincidence happens, we are amazed, and we applaud it. Frank Roberts, in his article, "Why we enjoy coincidences", borrows Jacques Monod's definition of coincidence, "McDermott quotes Jacques Monod on coincidence: 'The convergence of two totally-independent causal chains of events, the convergence itself being causeless." (Roberts, 1991, p. 290)

The idea of unconscious choices shaping our life seems to have been utilised abundantly in the silent films of Buster Keaton and Charles Spencer Chaplin. These two great masters of the silent era of cinema, though organically divergent - one believed in the idea of pure comedy; other in the tragic-comedy, discovered the cavernous aspects of life-rationally inexplicable, through a subtle application of coincidence. The screen personae of Charles Chaplin and Buster Keaton, respectively The Little Tramp and the Little Fellow, become their mouthpieces.

The fame of silent cinema itself was just an instance of serendipity. Following Walter Kerr: "While Edison was still searching for a satisfactory means of adding his new invention to the dominant phonograph, something unexpected happened. Large numbers of people became avidly interested in the pictures as pictures, whether they could talk or not." (Kerr, 1975, p. 7) This is how silent films came into public interest - not by intention but by chance. The requirement of comic elements in the silent comedies was also a rationale that led to the employment of unexpected events inexplicable by the laws of natural sciences. A film with rational events would hardly fetch any gag. For instance, there is a scene in The Navigator (1924) description to which goes as follows:

First each walks purposefully down the long, vacant starboard deck, the girl, then Keaton, turning the corner just in time not to see each other. Next time around each of them is trotting briskly, very much in earnest; going at the same pace, they miss each other just the same. Next time around each of them is going like a bat out of hell. Again they miss. Then the camera withdraws to a point of vantage at the stern, leans its chin in its hand and just watches the whole intricate superstructure of the ship as the protagonists stroll, steal and scuttle from level to level, up, down and sidewise, always managing to miss each other by hair's-breadths, in an enchantingly neat and elaborate piece of timing. (James Agee in Perez, 1981, p. 342)

After this long episode of chasing one another in the ship when Rollo Treadway and Betsy O'Brien stop for a moment to hold their breath, Rollo falls from the above precisely beside Betsy. The process becomes a reason for laughing with a deeper meaning embedded into itthe effort from our side does not necessarily lead to our desired consequence.

Both the filmmakers provide us with many such subtle functions of coincidence. In the movies of Buster Keaton while these events assist the protagonist in his purpose, on the other hand, in the case of Chaplin these elements, although happen to be successful in producing gags, hardly assist the Tramp in liberating him with his pre-existent state. Although, almost all the movies of both the filmmakers are interspersed with the instances of coincidences, nonetheless, some films are more celebrated than the others. The article under discussion will draw all the instances from some of these well-known films of these two showmen. The Navigator (1924) and The General (1926) of Keaton; City Lights (1931) and Modern Times (1936) of Charlie Chaplin are the films that have been taken for discussion in the article. 


\section{The Illusion of Free Will and the Prominence of Coincidence in the Films of Buster Keaton and Charlie Chaplin}

\section{The Illusion of Free Will and The Prominence of Coincidences in Life}

Free will, which is often considered synonymous to the freedom of choice-making, is not only socially constrained $d^{1}$ but also naturally constrained ${ }^{2}$. Sam Harris announces that "given the unconscious origins of our conscious minds", the idea of "free will is an allusion"(2012, p.17). We don't choose what we choose because we are consciously aware of it but only because we are unconsciously constrained to choose it. Freedom of choice, that is often taken as a central element of the Existential thinking, may not always work accordingly. Harris' treatment of free will differs from Sartre's idea of free will at great extent. Sartre claims in "Existentialism is a Humanism":

Everything is indeed permitted if God does not exist, and man is in consequence forlorn, for he cannot find anything to depend upon either within or outside himself. He discovers forthwith, that he is without excuse. For if indeed existence precedes essence, one will never be able to explain one's action by reference to a given and specific human nature; in other words, there is no determinism - man is free, man is freedom. (Sartre, 2016, p. 425)

Sartre's argument propounds that human beings are responsible for whatever they become in their life while Sam Harris debates just opposite. The argument put forward at this point does not connote that Sartre was not aware of constrained nature of choices, and it is perhaps because of this reason why he made the statement: "man is condemned to be free." (Sartre, 2016, p. 426) But he affirms that human beings are fully conscious of what they choose, and consequently responsible for their deeds. Harris claims that we don't understand what we choose for ourselves, leaving a little space for Sartre's idea of responsibility. It is certainly not the case with Sam Harris, unlike Sartre, "that beliefs are chosen." (Haynes-Curtis, 1988, p. 270)

Even if we ignore the determiners of free will mentioned above and bargain the consequences, we find that there is no proportional relationship between the choices we make and the results we get. Gunther S. Stent, in "Paradoxes of free will" aptly makes the following argument:

"The notion of free will attributes to persons the capacity to choose autonomously among possible alternative actions. This presumed autonomy of the will does not imply that a person's volition is totally immune to influence by other persons or by the natural world." (Stent, 2002, p. 1)

Taking the argument as mentioned earlier into account, we can understand how some factors always present in the background affect the outcome we intend to achieve by practising our freedom of choice making. Although we are fully aware that "our choices depend on prior causes does not mean that they don't matter" (Harris, 2012, p. 35), but at the same time, we should learn to acknowledge the other participating factors too.Sometimes, these factors that happen to run in the background of the actions - based on our free choices, overpower the participatory value of choices resultant of free will, leading us to chaotic results. "[The] meaning of freedom [that] is an opposite of determinism" (Stent, 2002, p.126) only means that we can alter the consequences, but the fact does not guarantee that the alteration will be the same as we prefer it, which ruins all the privileges of free will. This is why we are creatures with a strange predicament. The following example mentioned in Free Will, will make our position perspicuous:

Let's say your life is gone off track. You used to be very motivated, inspired by your opportunities, and physically fit, but now you are lazy, easily discouraged, and overweight. How did you get this way? You might be able to tell a story about how your life unraveled, but you cannot truly account for why you let it happen. And now you want to escape this downward trend and change yourself through an act of will. 
You begin reading self-help books. You change your diet and join a gym. You decide to go back to school. But after six months of effort you are no closer to living the life you want than you were living before $[\ldots]$

But you woke up this morning feeling even greater resolve. Enough is enough! Now you have a will of steel. Before stepping out of bed you had a brilliant idea for a website - and the discovery that the domain name was available for only 10 dollars has filled you with confidence. You are now an entrepreneur! You share the idea with several smart people, and they think that it is guaranteed to make you rich.

The wind is at your back, your sails are full and you are tacking furiously [...] Your friends can't believe what you have accomplished. Even your enemies begin to ask for your advice. (Harris, 2012. pp. 36-37)

Sam Harris' idea of sudden and random success based on coincidences corresponds to the descriptions of many scenes in the films of Chaplin and Keaton like the chase scene in The Navigator mentioned in the prefatory section of the article. Coincidence happens to be involved in both-making the choices as well as its consequences. It is nearly ridiculous to hold someone absolutely responsible for his/her deposition because free will plays only a minimal role in what we become in our life.The films of Chaplin, as well as of Keaton, offer a plethora of such instances.

\section{Coincidence in Charlie Chaplin's Films}

Chaplin's filmmaking career can be divided into two prominent parts: the first part happens to be related to his silent films, and the second is about his sound films. Both the films discussed here belong to his silent films. In City Lights, the Tramp (Chaplin) meets the flower girl(Virginia Cherrill). The girl is blind, and she mistakes Chaplin for a millionaire since she hears the honking of a car. Chaplin decides to stay with the Bad faith ${ }^{3}$, and does not reveal that he is a tramp who cannot arrange even for his bread and butter. The Tramp's behaviour throughout the film becomes a consequence of the coincidence - the honking of the car. "The story revolves around the little tramp's love for a blind flower girl, who mistakes him for a wealthy gentleman.” (Davis, 2003, p. 48)

Chaplin does not appreciate the idea of hierarchy in choice making, rather he embraces whatever comes in his way with an equal amount of warmth. It is the reason, perhaps, why he ironically employs the Little Tramp to behave like a gentleman, at least before the blind girl, except for the fact that the Tramp needed to search for some jobs in order to make a living in the city. Charles Silver points out: "The Tramp's polite tenderness, posing as a gentleman of means and purity of their courtship are intercut with Charlie's effort to cope up with folly and frenzy of city life, the urbane juxtaposed with urban"( Silver, 1989, p. 33). The film depicts an identifiable notion with the idea of Sam Harris when the pretentious gentleman meets the real gentleman and prevents him from committing suicide. The Tramp utters his motivating remarks: "Tomorrow the birds will sing. Be brave! Face the life!" (Chaplin, 1931, 00:12:35) To which he is rewarded with the friendship of the millionaire: "I'm cured. You're my friend for life." (Chaplin, 1931, 00:14:49) Although the gentleman's promise appears to be a hoax when he refuses to recognise the Tramp in his sober state, nevertheless, the Tramp manages to exploit the gentleman's wealth to prove his purpose in maintaining the relationship with the flower girl. The meeting of the Tramp and the gentleman remains an act of pure coincidence in opposition to a responsible and conscious decision.

There are two pertinent examples from Modern Times that influence the plot of the movie. The first instance occurs when the Tramp, after being treated for his so-called nervous 


\section{The Illusion of Free Will and the Prominence of Coincidence in the Films of Buster Keaton and Charlie Chaplin}

breakdown, is discharged from the hospital. In search of a job, he walks on the road. At the same time, there is a protest going on there in the street. He is misunderstood as "the leader of the group" (Chaplin, 1936, 00:20:42) by the police and sent to the prison. The particular episode keeps on repeating throughout the movie as a running motif. The second instance takes place in the prison when Chaplin "having salted his food accidentally with a powdered drug" (Stewart, 1976, p. 301), helps the police recapturing the prisoners who were trying to escape. The event plays a vital role in the release of Chaplin.

The instances mentioned above from the Modern Times, exhibit, how the things that happen in the life of the Tramp are devoid of his active and conscious participation. Chaplin's existence-pleasant or unpleasant, in the movie, is shaped by coincidences. The clear picture of the illusion of free will is visible in the film. The sense of a planned life remains absolutely disapproved with the performance of the nonsense song ${ }^{4}$ towards the end of the film. The episode goes as follows: Pauline Godard decides to find out a job for the unemployed Chaplin, in a café. Unfortunately, there is a place only for a song performer in which, like in any other job, the Tramp has no expertise. After a long practice with the assistance of the Gamin (Paulette Godard), Chaplin is ready to perform the song. Since he cannot remember the lyrics, Paulette ties the lyrics written on a paper on his wrist. Just after performing a few gestures, the paper falls down from the Tramp's wrist and the coherence is lost. As a result, the plan is jeopardised and Chaplin has to perform in the absence of the lyrics. He works on Pauline's principle to "never mind the words" (Chaplin, 1936, 01:19:39) yet the show is a hit. Thus, Chaplin pays little attention to the highly constrained and personalised efforts of human beings. He does not make any conscious effort in his success; it is rather done in an unconscious way.

\section{Coincidence in Buster Keaton's Films}

Keaton has used the best of coincidence sequences in two of his films: The Navigator and The General. When asked in an interview: "Of the features, which is your favorite?" His reply was - "I have two-The Navigator and The General." (Bishop and Keaton, 1958, p. 17)

In The Navigator, Betsy's sudden rejection of Rollo's proposal does not affect his intent of honeymoon. Accidently, they are put on the same ship and "the next morning found the navigator drifting helplessly at sea." (2017, 00:10:21) The wrong ship takes Treadway to the right destination. As he wanted to be accompanied by Betsy on the trip, so it followed. Rollo and Betsy are all alone on a large ship - a metaphor for an island where two individuals explore each other's psyche. Towards the end of the film when they near to an inhabited island; the natives try to capture them. Amidst their efforts to escape, there is a scene in which Rollo tries aiming a cannon at a native, but the mouth of the cannon remains at himself as it got stuck to Rollo's feet. Nevertheless, at the moment when the cannon fires, Rollo bends down by chance, and the man he had targeted was shot. In an identical scene which Keaton employed in The General, the cannon avoids hitting Keaton only because there is a turn on the track at the exact moment when the cannon fires. In The General, Johnny Gray (Keaton) tries his best to prove his bravery to Annabelle Lee (Marion Mack). In the quest, he has to serve as a soldier since his country is at war. Whitney Kaufman, in his article "On the Ending of Buster Keaton's The General", has depicted how the protagonist finds himself between love and war:

In fact, the two heroic conventions (war and romance) are closely connected in The General. Annabelle's love for him is conditioned on his being a soldier and ultimately on his purported heroism, while the consent of her father and brother to the marriage is also dependent on their approval of him as a proper soldier. (2019, p.230) 
Since Johnny is an engineer, and in this profession, he can be exploited in a better way than by being a soldier. The officials decide to reject his application for going to war. The opposition steals his General, hereafter, we find Johnny directly involved in fighting against the enemy. Sam Harris, in Free Will, points out how it is the option that happens to be totally disconnected to our conscious effort, plays the most prominent role in getting what we desire. Likewise, Keaton gets what he wants but not as a consequence of conscious effort, on the contrary, as a consequence of a random event.

One of the best episodes takes place when Keaton accidentally arrives in the territory of the enemy and finds himself in the same building where the enemy's most secret discussion is going on. At the same time, he comes to know that Anna has been captured and kept in the same building by the enemy. He rescues Anna from the building on which she proudly claims: "It was so brave of you to risk your life and coming to enemy's country, just to save me." (2014, 00:42:08) Annabelle wants Jonnie to be brave, which he becomes, but only by chance and not by choice.

\section{The Little Tramp, the Little Fellow, and the Function of Coincidence}

Both the personae-The Little Tramp and the Little Fellow seem to be in a complete agreement when it comes to Sam Harris's idea of the illusion of free will. The Little Tramp, as well as the Little Fellow, apply similar means to fulfil their purposes, but it does not mean that they aspire for the same ends. In the case of former, we encounter an extremely suffocating and fallible world which, in most of the times, cannot be set right because the coincidences are followed by chaotic situations. For instance, in Modern Times, The Little Tramp manages to be successful through his song of nonsense, but what follows is quite horrible, and it does not end in his favour. The case of the latter is quite contrary. In The Navigator, for example, it is the same moment when he is about to drown that the submarine emerges from the water and rescues Betsy and Rollo marking the film with a happy ending.

Buster Keaton's protagonist, unlike The Tramp, does not emerge from poverty and imprisonment but he always happens to be part of some class of society or institution. "Chaplin conceives excess necessarily occupying a position outside the social order, whereas Keaton shows that it can be present in society and disrupt it from within. This orientation is the essence of the distinction between the two comedians" (McGowan, 2016, p. 603). Treadway is a rich man, and his fall is not permanent. After some days of struggles in the ship sailing at the vast sea, he reaches a state that is equivalent to redemption. Buster Keaton comments on his method of fleeting fracas:

In laying out The Navigator for instance, we're going to end by putting two people adrift on an ocean liner and it's a dead ship-there are no lights on it, no water, nobody to wait on them. Well, all right. Now you go back to your first part to establish your character. Well if I was a laborer or a poor guy, or something like that-it would be no hardship for me to be on that ocean liner. But if I started out with a Rolls Royce, a chauffeur, a footman, a valet, and a couple of cooks and everything else to wait on me-and the same thing with the girl-in other words, the audience knows we were born rich, and never had to lift a finger to do anything. Now you turn those two people adrift on a dead ship, they're helpless. (Bishop and Keaton, 1958, p. 21)

The Little Tramp, on the other hand, happens to be a permanently exiled man and is unable to fit in any class. The sets of coincidences implied in the films of Chaplin under discussion fail to make any substantial change in the Tramp's situation. Where Keaton's films end with the self-preservation of the Little Fellow, Chaplin employs all the techniques for the humiliation of The Little Tramp. Chaplin's mission remains one and firm which is 


\section{The Illusion of Free Will and the Prominence of Coincidence in the Films of Buster Keaton and Charlie Chaplin}

identical to Martin Esslin's view of Arthur Adamov's plays where "Only task left to man is to tear off all that dead skin until 'he finds himself in the hour of the great nakedness." (Esslin, 2001, p. 91) In the films starring The Little Tramp, Chaplin seems to have been following his statement which he had made in an interview with Frank Vreeland in 1921: 'I love to tear things apart. I don't like them as they are.' (Vreeland 1921, p. 51)The ending scene of City Lights, one of the most poignant scenes in the history of motion picture, shows the Tramp wandering on the footpath while the kids selling the newspaper make fun of him. When he encounters the flower girl who now is capable of seeing, cannot recognise him, as their relationship was limited up to the tactile senses. The triumph that the Tramp feels towards the end is objectively oriented to the purpose of the girl. There is no suggestion that the Tramp will find any place in the life of the girl. Similar occurrences are prevalent in Modern Times as well. The Tramp seems to have found a job with a promise to lead a harmonious life with the girl, but it is the same time when the police arrive for the arrest of the girl as she is wanted and they have to leave their almost established life. Richard Carr, in his book Charlie Chaplin: A Political Biography from Victorian Britain to Modern America, has rightly distinguished the position of the Tramp from the Keaton's Silent Fellow:

For Keaton, his creation was a member of the virtuous working class: 'My little fellow was a workingman and honest.' But 'Charlie's tramp was a bum with a bum's philosophy. Loveable as he was he would steal if he got the chance.'[...] Fundamentally, if either creation wanted to buy a suit he saw in a shop window, Keaton's character would 'start to figure out how he could earn extra money to pay for it' whereas Charlie's would either 'steal the money ... . [or] forget all about the suit' $[. .$.$] The Tramp was, in other words, a pauper condemned to perpetual poverty.$ (2017, p.67)

It is the 'perpetual poverty' of the Little Tramp that makes the plot of Chaplin's movies progress in the opposite direction than that of Keaton's.

\section{Analysing the Beginning, the Middle, and the End}

In the opening scene of The City Lights, we find The Tramp "sleeping like a baby in the lap of a woman. Unfortunately, she is made of stone, one of three figures symbolising "peace and prosperity.' For Charlie as usual, there is neither, and his sojourn in lap is interrupted by the unveiling of statue before an assembled throng." (Silver, 1989, p. 33) There is no place for the Tramp in the society as he is unable to find refuge anywhere, and his presence is unsolicited for the people. The opening scene of The Navigator portrays Rollo with his servant discussing to get him a ticket for his honeymoon. The point of crisis, in the film, reaches when the Little Fellow has been dejected, against his expectations, by his neighbour. The event turns Rollo's life upside down, and he decides to take a break from the hubbubs of the world. Modern Times begins with the message: "A story of industry, of individual enterprise-humanity crusading in the pursuit of happiness." (1936, 00:01:17) We encounter a man who has been internalised with the mechanism of machine. The prefatory of The General shows a man "in the spring of 1861" (2014, 00:01:04), on an ordeal - to prove his love by getting enlisted as a soldier. The Little Fellow, as a protagonist, appears to be more capable of making a choice than The Tramp.

There are visible pieces of evidence, both in Chaplin as well as in Keaton, that they do not totally ignore their freedom of choice-making, and employ them time to time, resulting only in failures. For instance, at one point in City Lights, Chaplin makes a conscious decision of fighting a match of boxing in which he has been promised by his opponent that he would not hurt him, and they would split the money fifty-fifty. Unfortunately, his opponent had to 
run away just when the match was about to begin. The Tramp is made to fight with another boxer and is beaten until he faints. Jonny Gray tries twice to enlist as a soldier-for the first time he gives his real identity but when he is aware of the fact that he was rejected because his former occupation was more profitable to the state than to exploit him as a frontier of war; he tries with changed identity for the second time but only in vain. The Tramp, in Modern Times, brings forth all his effort to perform his song with the help of the girl, but he had to perform it without lyrics though it led to an unprecedented applaud. When Rollo takes up the task of liberating Betsy from the attack of the natives, he ends up with the choices between dying by drowning and being killed by the natives. Both the actors offer us with the instances of choice making and its absurdity. The only difference is that the chances for exploiting free will comes only on rare occasions in Chaplin because "his tramp is of course, a perennial and permanent outsider, the stranger in the strangest of the lands, looking in the windows of the brightly lit party, himself as a shadowy silhouette in the darkness." (Silver, 1989, p. 25) The freedom of choice does not seem to be compatible with the result in the case of both Chaplin as well as Buster Keaton.

It is the endings of the films that differentiate between the philosophy of Keaton and Chaplin. At one hand where Chaplin used the continuous sequence of coincidences just to end in a tragic space, Keaton's usage of coincidence was meant for the ultimate good of the protagonist. Towards the end of City Lights, we find that the Tramp meets his millionaire friend one last time and manages the money for the surgery of the girl. In the last scene, he has been exposed before the girl to the same degree as he was before the people in the opening scene. There is a very little doubt that he will walk away from the life of the girl as he did in one of his early movies-The Tramp $(1915)^{5}$. Modern Times ends with the famous walking scene of the Tramp with an optimistic tone. He walks away in the expectations of finding a new space where he could find a sense of belonging. But we all know, for sure, that the Tramp is incapable of finding it. The following lines describe the position of the Tramp at best.

In opposition to modernist search for monolithic meaning in life, we find, in the world of the Tramp, the search for meaning happens to be of no worth. But it does not stop him from the search for meaning. Samuel Beckett's cry of failing again and failing better is heard at the best in Chaplin's movies related to The Little Tramp but at the same time we know that the best can never be reached: It is simply because the stone of meaning has to tumble down after it has reached a certain height - the reliability of meaning is highly temporal and spatial. (Verma and Mishra, 2020, p. 6)

On the contrary, Keaton's films end with the protagonist's purpose achieved. In the beginning of the films, the Little Fellow yearns for something, and in the end, he gets it. Although he cannot find it with conscious effort, the coincidences end in his favour. In The Navigator, Rollo has not only been saved from drowning but also, he finds his relationship mended with Betsy. The General ends with the victory of Jonnie's country in which he plays a great role: "Johnnie Gray has conformed to social expectations and become a military hero and a romantic hero, and yet an odd sort of hero who both represents and refutes the tragicheroic conventions." (Kaufman, 2019, p. 232)

\section{Conclusion}

No matter that the motivations of employing the elements of coincidence were different in Buster Keaton and Charlie Chaplin, nevertheless, they were aware of the slippery nature of the relationship between conscious choice-making and its results. It is not only because the entertainment creating nature of the coincidental events attracted these two masters of silent comedy to use them, but also there was always a philosophical motif involved in it. They 


\section{The Illusion of Free Will and the Prominence of Coincidence in the Films of Buster Keaton and Charlie Chaplin}

represent a philosophy, most compatible with the ways of life. The Little Tramp and the Little Fellow make us realise that whatever we become in the course of life follows quite contrary to the notion of free will:

Not only are we not as free as we think we are-we do not feel as free as we think we do. Our sense of our freedom results from our not paying close attention to what it is like to be us. The moment we pay attention, it is possible that free will is nowhere to be found, and our experience is perfectly compatible with this truth. Thoughts and intentions simply arise in the mind. The truth about us is stranger than many suppose: the illusion of free will is itself an illusion. (Harris, 2012, p. 56)

Thus, the films of Chaplin and Keaton exploit the coincidence for uncovering deeper layers of human life. However, when it comes to portraying the reality of human predicament, Chaplin seems to be more convincing than Keaton as the Little Tramp unlike the Little Fellow does not walk only on the bright path but also wanders through the chaotic situations corresponding to the nature of human life. Nevertheless, both Keaton and Chaplin are not only aware that "coincidence is a subject which many find fascinating and delightful" but also conscious that the idea of coincidences shaping our life cannot be neglected. (Roberts, 1991, p. 290)

\section{Endnotes}

${ }^{1}$ The freedom of choice-making depends upon what kind of society we live in.

${ }^{2}$ Our choices are limited by geographical conditions. For instance, we cannot live somewhere with extremely low temperature and chose not to wear warm clothes at the same time.

${ }^{3}$ It is synonymous to self-deception. French philosopher Jean-Paul Sartre has propounded this idea in the chapter "Bad Faith" of his book Being and Nothingness.

${ }^{4}$ The lyrics of the song do not comprehend to any language. Watch Modern Times from $1: 18: 58$ to $1: 22: 17$.

${ }^{5}$ This is one amongst the earliest films starring the Little Tramp. Towards the end of the film, the Tramp leaves the girl he is in love with when he finds himself creating disharmony in her life which became a recurrent motif in most of Chaplin's silent films.

\section{References}

Carr, R. (2007). Charlie Chaplin: A Political Biography from Victorian Britain to Modern America. Routledge.

Chaplin, C. (1964). My Autobiography. Penguin books.

City Lights. MUBI. (1970, January 1). https://mubi.com/films/city-lights

Davis, T. (2003). First Sight: Blindness, Cinema and Unrequited Love. Journal of Narrative Theory, 33(1), pp. 48-62. https://doi.org/10.1353/jnt.2011.0067.

Esslin, M. (2001). The Theatre of the Absurd. Vintage eBooks, A Division of Random House, Inc.

Harris, S. (2012). Free Will. Free press. Libgen, http://libgen.rs/book/index.php?md5=EFA9A66A435EF4FF473AF350B9E78D1D.

Haynes-Curtis, C. (1988). 'Faith' of Bad Faith. Cambridge University on behalf of Royal Institute of Philosophy, 63(244), pp. 269-275. https://www.jstor.org/stable/3750419

Kaufman, W. (2019). On the Ending of Buster Keaton's The General. Journal of Popular Film and Television, 47:4, pp. 227-232. https://doi.org/10.1080/01956051.2019.1568226 
Kerr, W. (1975). The Silent Clowns. Alfred A. Knopf.

Laurel \& Hardy. (2017, December 11). The Navigator (1924) Buster Keaton. [Video]. YouTube. https://www.youtube.com/watch?v=tXPhzEfHf58

McGowan, T. (2016). The Location of Silent Comedy: Charlie Chaplin's Outsider and Buster Keaton's Insider. Quarterly Review of Film and Video, 33(7), pp. 602-619. https://doi.org/10.1080/10509208.2015.1094335

Modern Times. MUBI. (1936). https://mubi.com/films/modern-times/watch

Perez, G. (1981). The Bewildered Equilibrist: An Essay on Buster Keaton's Comedy. The Hudson Review. 34(3), pp. 337-366. https:// www.jstor.com/stable/3856854

Roberts, F. (1991). Why We Enjoy Coincidences. New Blackfriars, 72(850), pp. 290-295. https:// www.jstor.org/stable/43249026

Sartre, J. P. (2016). Existentialism is a Humanism. Existentialism from Dostoyevsky to Sartre. In Walter Kaufman (Ed), pp. 318-449. Pickle Partners Publishing

Silver, C. (1989). Charles Chaplin: An appreciation. The Museum of Modern Art. https://www.moma.org/documents/moma_catalogue_2136_300062892.pdf

Stassi, F. (2014). Charlie Chaplin's Last Dance. (Stephen Twilley, trans.) Portobello books.

Stent, S. G. (2002). Paradoxes of Free Will. Transactions of the American Philosophical Society 92(6), pp. $i-i i i+v-i x+x i-x i i+1-261+263-273+275-284$. https:// www.jstor.org/stable/4144913

Stewart, G. (1976). Modern Hard Times: Chaplin and the Cinema of Self-Reflection. Critical Inquiry, 3(2), 295-314. https://doi.org/www.jstor.org/stable/1342891

UHF Channel 58. (2014, August 08). Buster Keaton in the General [Video]. YouTube, https://www.youtube.com/watch?v=iHIBMKtgPOA.

Verma, S.P. \& Binod Mishra. (2020). The Art of Survival: Understanding Charlie Chaplin's The Little Tramp through the Lens of Little Narratives. Quarterly Review of Film and Video. https://doi.org/10.1080/10509208.2020.1777051

Vreeland, F. (2005). Charlie Chaplin, philosopher, has serious side. In K. J. Hayes. (Ed.). Charlie Chaplin Interviews, pp. 51-63. Mississippi University Press.

\section{$\underline{\text { Bio-note }}$}

Surya Prakash Verma is a $\mathrm{PhD}$ scholar at the Department of Humanities and Social Sciences, IIT Roorkee, India. He is working on the topic 'Exploration of Charlie Chaplin's The Little Tramp Screen-persona in Select Films: A Postscript to The Myth of Sisyphus.' ORCID id: https://orcid.org/0000-0002-0059-4713

Email id: surya2145536@gmail.com.

Binod Mishra is a Professor of English at the Department of Humanities and Social sciences, IIT Roorkee, India. He has published and presented research papers widely. $\mathrm{He}$ has also authored and edited a good number of seminal books. He has prepared and participated in EContent Development of Language Learning Programs under NPTEL conducted by the Ministry of Higher Education, Govt. of India. He is the Vice Chairman of Association for English Studies of India and has also been Editor-in Chief of Indian Journal of English Studies of India for six years.

Email id: binodfhs@iitr.ac.in/mishra.binod@gmail.com 